\title{
THEATRE FOR A NEW AUDIENCE
}

\section{$360^{\circ} \mathrm{S} \mathrm{E} \mathrm{R} \mathrm{I} \mathrm{E} \mathrm{S}$}

\author{
VIEWFINDER: FACTS AND PERSPECTIVES \\ ON THE PLAY, PLAYWRIGHT, AND PRODUCTION
}

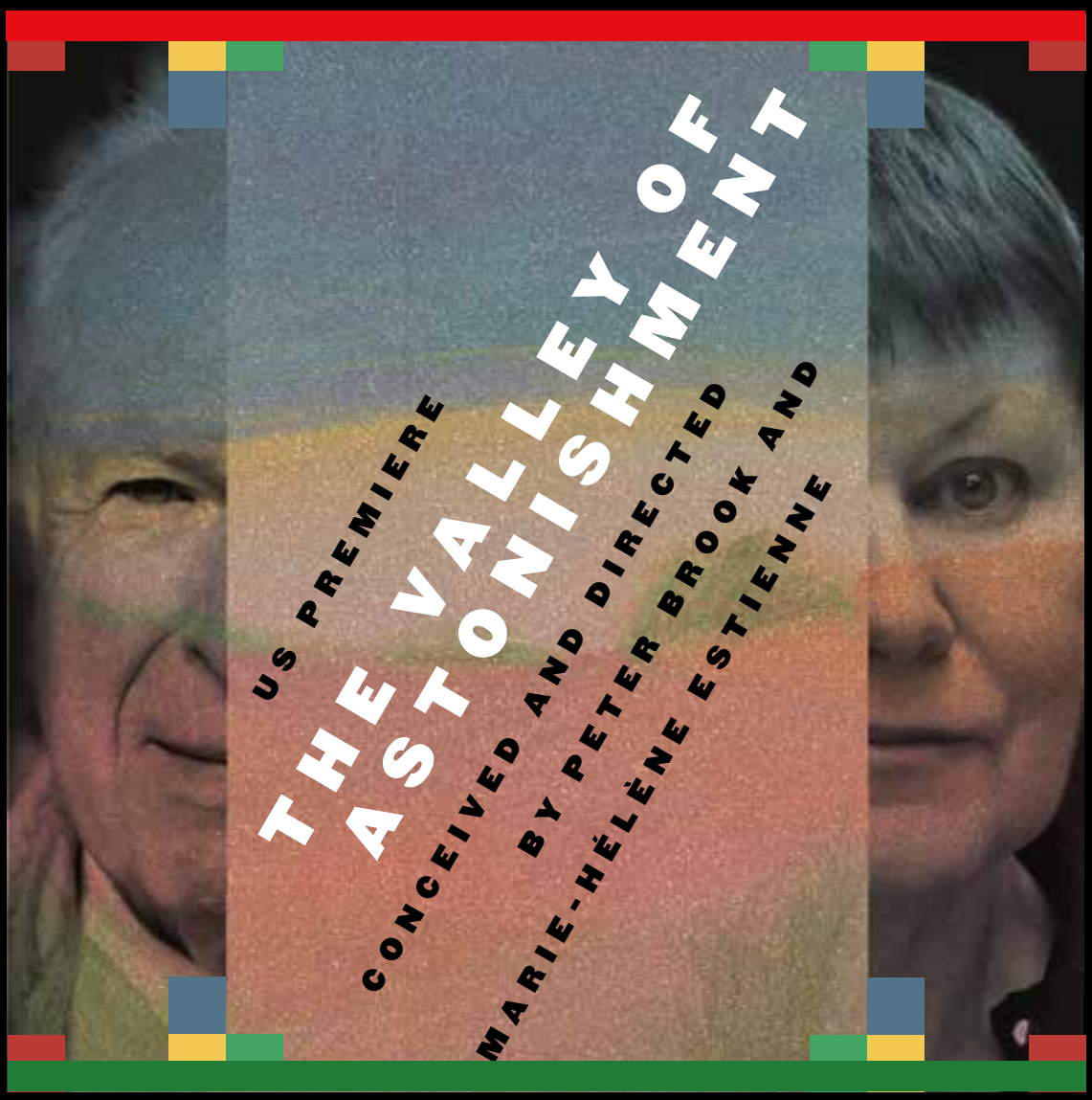




\section{The Play}

3 An Introduction from Peter Brook

4 Dialogues: From 'The Key of Clear Green'

by Oliver Sacks, M.D.

7 Mandalas: An Installation Inspired by The Valley of Astonishment

\section{The Production}

9 Dialogues: On the Making of The Valley Of Astonishment, An Interview With Peter Brook by James Woodall

11 Cast and Creative Team

\section{About Theatre For a New Audience}

16 Mission and Programs

17 Major Supporters

The Valley of Astonishment is a C.I.C.T. / Thêâtre des Bouffes du Nord production, co-produced by Theater for a New Audience, New York; Les Théâtres de la ville de Luxembourg; Théâtre d'Arras / Tandem Arras-Douai; Théâtre du Gymnase, Marseille; Warwick Arts Center; Holland Festival, Amsterdam; Attiki Cultural Society, Athens; Musikfest Bremen; Théâtre Forum Meyrin, Geneva; C.I.R.T. and Young Vic Theatre, London.

The Valley of Astonishment premiered at Thêâtre des Bouffes du Nord, Paris on April 29th, 2014.

The producers would like to thank Franck Krawczyk, Carol Steen, Jon Adams, Daniel Tammet, Dr. Oliver Sacks, Professor Simon BaronCohen, Dr. Richard Cytowic, Ian Waterman, Dr. Jonathan Cole, Oria Puppo, Philippe Beau, Pat Duffy, and James Rutherford.

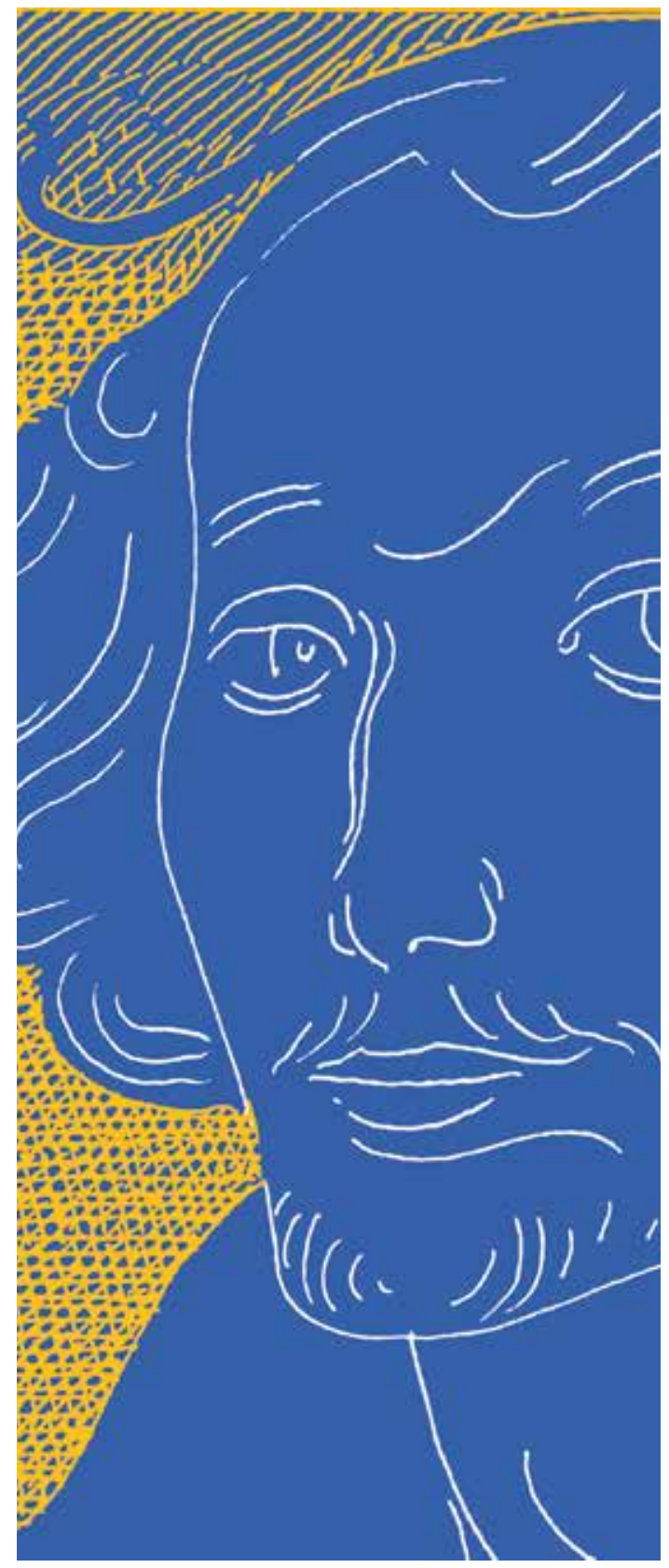

\section{Notes}

Front Cover Art: Peter Brook, photo by Colm Hogan; and Marie-Hélène Estienne, photo by Álvaro García; designed by Milton Glaser, Inc. This Viewfinder may be periodically updated with additional information. Last updated September 2014.

\section{Credits}

The Valley of Astonishment $360^{\circ}$ | Compiled and edited by: Carie Donnelson | Literary Advisor: Jonathan Kalb | Council of Scholars Chair: Richard C. McCoy | Additional research by: Molly Yarn and Kelsey Shapira | Designed by: Milton Glaser, Inc. | Copyright 2014 by Theatre for a New Audience. All rights reserved. With the exception of classroom use by teachers and individual personal use, no part of this Viewfinder may be reproduced in any form or by any means, electronic or mechanical, including photocopying or recording, or by an information storage and retrieval system, without permission in writing from the publishers. Some materials published herein are written especially for our guide. Others are reprinted by permission of their authors or publishers. 


\section{THE PLAY AN INTRODUCTION FROM PETER BROOK}

If we go to the theatre, it's because we want to be surprised, even amazed. And yet we can only be concerned if we can feel a strong link with ourselves. So, these two opposite elements have to come together - the familiar and the extraordinary.

In The Man Who, our first adventure into the labyrinths of the brain, we met neurological cases who in the past had been conveniently written off as 'mad.' Our first surprise was to encounter beings like ourselves, whose condition made their behaviour totally unpredictable. Painful to watch, though often very comic, they were always touching-deeply human.

In The Valley of Astonishment, once again, we are exploring the brain. We will take the spectator into new and unknown territories through people whose secret lives are so intense, so drenched in music, colour, taste, images, and memories that they can pass any instant from paradise to hell and back again. We link this to the great Persian poem The Conference of the Birds. Thirty birds in their quest for a King have to cross seven valleys of mounting suffering and discovery. An amazing series of anecdotes from the life of the time with poetry and humour brings their story into sharp relief.

So as we explore the mountains and the valleys of the brain we will reach the valley of astonishment. As we go forward with our feet firmly on the ground, each step takes us further into the unknown.

\section{CHARACTER NOTES}

The character of Samy Costas is inspired by Solomon

Shereshevsky's life which was made public by Alexander Luria in his book The Mind of a Mnemonist.

The character of the magician is inspired by René Lavand.

\section{PETER BROOK}

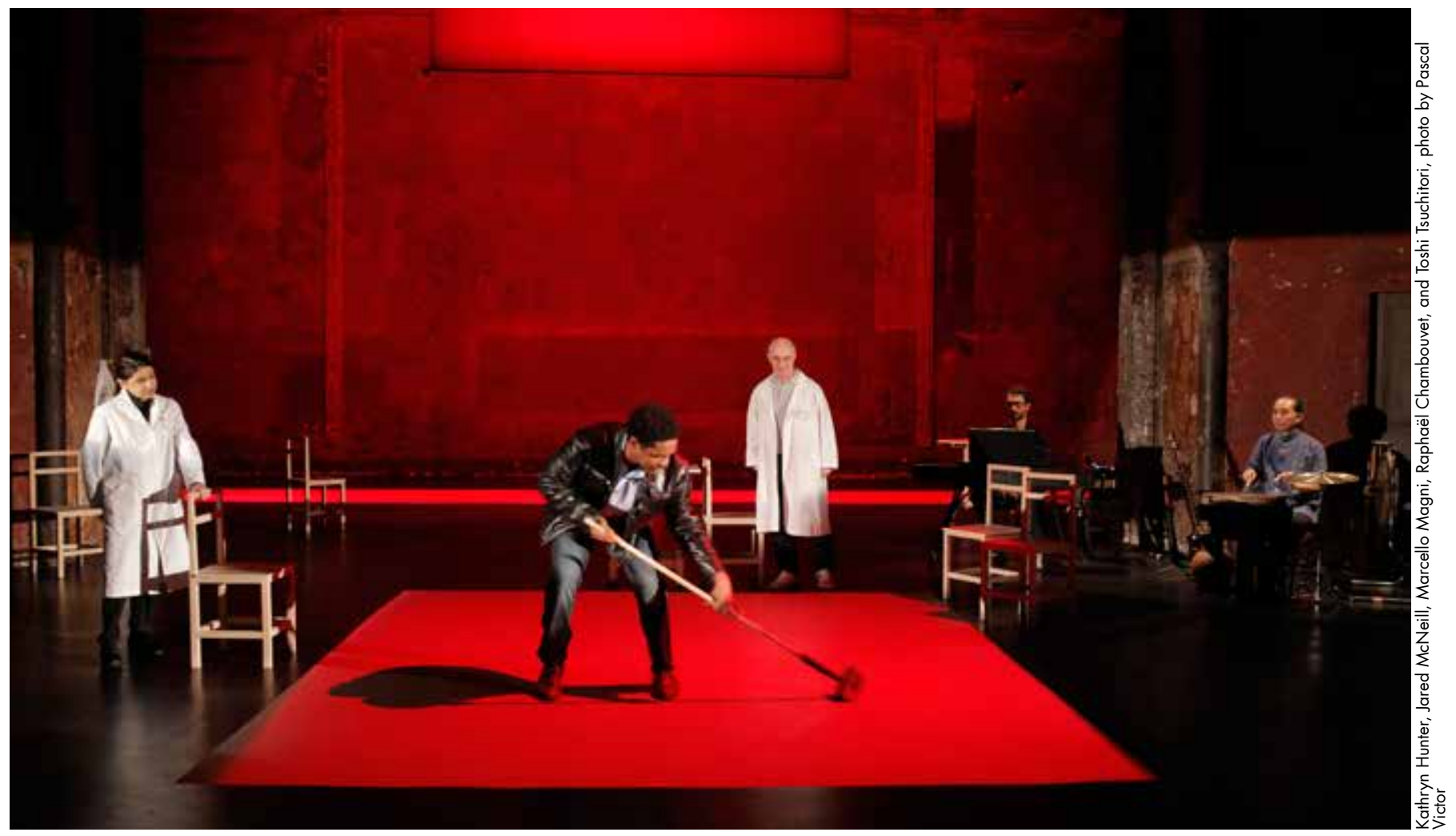




\section{DIALOGUES FROM 'THE KEY OF CLEAR GREEN'}

\section{OLIVER SACKS, M.D.}

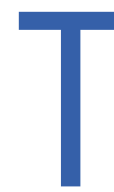

he history of scientific interest in synesthesia has gone through many vicissitudes. In the early nineteenth century, when Keats and Shelley and other poets used extravagant intersensory images and metaphors, it seemed that synesthesia was no more than a poetic or imaginative conceit. Then came a series of careful psychological studies in the 1860s and 1870s, culminating in Galton's Inquiries into Human Faculty and Its Development in 1883. These served to legitimate the phenomenon and were soon followed by the introduction of the word "synesthesia." Towards the end of the nineteenth century, with Rimbaud and the Symbolist poets, the notion of synesthesia again seemed a poetic conceit, and it ceased to be regarded as a subject for scientific investigation. ${ }^{1}$ This changed yet again in the last third of the twentieth century, as John Harrison details in his excellent book Synaesthesia: The Strangest
Thing. In the 1980s, Richard Cytowic made the first neurophysiological studies of synesthetic subjects—studies that, for all their technical limitations, seemed to show a genuine activation of different sensory areas in the brain (e.g., auditory and visual) coincident with synesthetic experiences. In 1989, he published a pioneering text, Synesthesia: A Union of the Senses, and this was followed by a popular exploration of the subject in 1993, The Man Who Tasted Shapes. Current techniques of functional brain imaging now give unequivocal evidence for the simultaneous activation or coactivation of two or more sensory areas of the cerebral cortex in synesthetes, just as Cytowic's work had predicted.

Anatomical plate in Frederik Ruysch's "Icon durae matris in convexa [concava] superficie visae..." by Jan L'Admiral, c. 1738; @ The Trustees of the British Museum

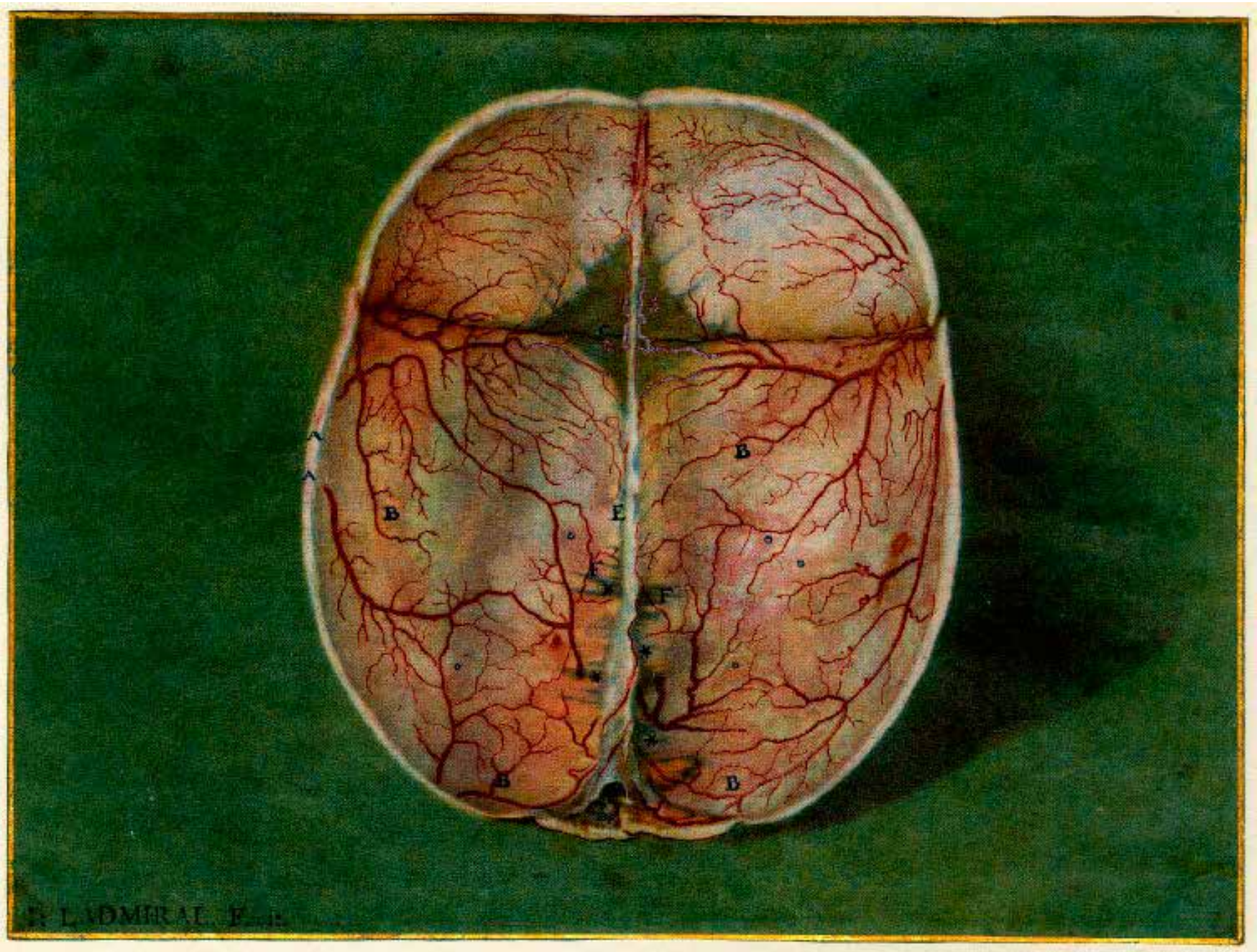




\section{FROM 'THE KEY OF CLEAR GREEN: SYNESTHESIA AND MUSIC' OLIVER SACKS}

While Cytowic was investigating synesthesia in the United States, Simon Baron-Cohen and John Harrison were opening up the subject in England, and in 1997 they published a review volume, Synaesthesia: Classic and Contemporary Readings.

Galton believed that genuine synesthesia was strongly famil$\mathrm{ial}$, and Harrison and Baron-Cohen noted that a third of their subjects reported close relatives who also had synesthesia. Nabokov, in his autobiography, Speak, Memory, wrote of how as a child he saw all the letters of the alphabet as having distinct colors and was deeply upset when he was given a box of colored letters and found that nearly all of them were the "wrong" color. His mother, also a synesthete, agreed with him that the colors were wrong, but not on what they should be. (Nabokov's wife, too, was a synesthete, as is their son.)

While synesthesia has been regarded as quite rare, affecting perhaps one person in two thousand, and to have a strong gender preference (with a female to male ratio of about six to one), a recent study by Julia Simner, Jamie Ward, and their colleagues has brought both of these suppositions into question. Using a random population of almost seventeen hundred subjects, and objective tests to separate genuine from pseudosynesthesia, they found that one person in twentythree had some kind of synesthesia-most commonly for colored days — and that there was no significant gender difference. ${ }^{2}$

Prior to 1999, there were no objective psychological tests for synesthesia. But in the past few years, V. S. Ramachandran and E. M. Hubbard have brought great experimental ingenuity to the testing of this. In order to distinguish true synesthesia from pseudosynesthesia, for example, they have devised tests that only a genuine synesthete can "pass." One such test (described in their 2001 paper in the Journal of Consciousness Studies) presents the subject with a medley of rather similar-looking 2's and 5's, all printed in black. The ordinary person would be hard put to distinguish these at a glance, but a color-number synesthete can distinguish them easily by their different "colors."

Functional brain imaging has now confirmed that there is activation of visual areas (especially color-processing areas) in synesthetes when they "see" colors in response to speech or music. ${ }^{3}$ There is little room for doubt, anymore, as to the physiological as well as the psychological reality of synesthesia.

Synesthesia seems to go with an unusual degree of crossactivation between what, in most of us, are functionally independent areas of the sensory cortex-such cross-activation could be based on an anatomical excess of neural connections between different areas of the brain. There is some evidence that such "hyperconnectivity" is indeed present in primates and other mammals during fetal development and early infancy, but is reduced or "pruned" within a few weeks or months after birth. There have not been equivalent anatomical studies in human infants, but as Daphne Maurer of McMaster University notes, behavioral observations of infants suggest "that the newborn's senses are not well differentiated, but are instead intermingled in a synaesthetic confusion."

Perhaps, as Baron-Cohen and Harrison write, "we might all be colored-hearing synesthetes until we lose connections between these two areas somewhere about three months of age." In normal development, according to this theory, a synesthetic "confusion" gives way in a few months, with cortical maturation, to a clearer distinction and segregation of the senses, and this in turn makes possible the proper cross-matching of perceptions which is needed for the full recognition of an external world and its contents-the sort of cross-matching which ensures that the look, the feel, the taste, and the crunch of a Granny Smith apple all go together. In those individuals with synesthesia, it is supposed, a genetic abnormality prevents complete deletion of this early hyperconnectivity, so that a larger or smaller remnant of this persists in adult life.

Synesthesia seems to be commoner in children. As early as 1883, the same year that Galton's book was published, the eminent psychologist Stanley Hall described music-color synesthesia in 40 percent of children interviewed-a figure which may err on the high side. But a variety of more recent studies agree that synesthesia is a good deal commoner in childhood and tends to disappear at adolescence. Whether this goes with hormonal changes or cerebral reorganizations, which are both occurring at this time, or with a movement 


\section{FROM 'THE KEY OF CLEAR GREEN: SYNESTHESIA AND MUSIC' OLIVER SACKS}

to more abstract forms of thinking is unclear.

While synesthesia usually appears very early in life, there are rare situations which may provoke its appearance later in life-for example, it can occur transiently during temporal lobe seizures or under the influence of hallucinogens.

But the only significant cause of permanent acquired synesthesia is blindness. The loss of vision, especially early in life, may lead, paradoxically, to heightened visual imagery and all sorts of intersensory connections and synesthesias. The rapidity with which synesthesia can follow blindness would scarcely allow the formation of new anatomical connections in the brain and suggests instead a release phenomenon, the removal of an inhibition normally imposed by a fully functioning visual system. In this way, synesthesia following blindness would be analogous to the visual hallucinations (Charles Bonnet syndrome) often associated with increasing visual impairment or the musical hallucinations sometimes associated with increasing deafness.

OLIVER SACKS, M.D. is a physician, a best-selling author, and a professor of neurology at the NYU School of Medicine.

He is best known for his collections of neurological case histories, including The Man who Mistook his Wife for a Hat (1985), Musicophilia: Tales of Music and the Brain (2007) and The Mind's Eye (2010). Awakenings (1973), his book about a group of patients who had survived the great encephalitis lethargica epidemic of the early twentieth century, inspired the 1990 Academy Award-nominated feature film starring Robert De Niro and Robin Williams. The New York Times has referred to him as "the poet laureate of medicine."

Dr. Sacks is a frequent contributor to the New Yorker and the New York Review of Books, and a fellow of the American Academy of Arts and Letters as well as the American Academy of Arts and Sciences.

\section{NOTES}

Excerpt reprinted with the permission of Random House, Inc. from "The Key of Clear Green: Synesthesia and Music," in Musicophilia, pages 191195. Copyright (C) 2008 by Vintage Books. All rights reserved.

1 A striking exception was The Mind of a Mnemonist, A. R. Luria's 1968 study of a synesthetic memorizer. For Luria's subject, Shereshevsky, "there was no distinct line, as there is for others of us, separating vision from hearing, or hearing from a sense of touch or taste." Every word or image Shereshevsky heard or saw, every perception, instantly gave rise to an explosion of synesthetic equivalences - and these were held in mind, precisely, indelibly, and relentlessly for the rest of his life.

2 Synesthesia literally means a fusion of the senses, and it is classically described as a purely sensory phenomenon. But it is becoming clear that there are conceptual forms of synesthesia, too. For Michael Torke, the idea of seven is golden-whether this is an Arabic 7 or a Roman VII. Some people have an instant and automatic conjoining of other categorical characteristics — for example, they may see certain days of the week as male or female, or certain numbers as "mean" or "kind." This constitutes a sort of "higher" synesthesia, a union of ideas rather than sensations. For such synesthetes, these are not whims or fancies but fixed, irresistible, and lifelong correspondences. Such conceptual forms of synesthesia are being investigated especially by Julia Simner and her colleagues, and by V. S. Ramachandran.

3 See, for example, Paulescu, Harrison, et al. 
The Mandalas created by artist and synesthete Carol Steen are featured in the Irving Harris Foundation Lobby of Polonsky Shakespeare Center through the run of The Valley of Astonishment.

\section{A MESSAGE FROM PETER BROOK AND MARIE-HÉLÈNE ESTIENNE}

When we began our research for The Valley of Astonishment we wanted to meet some synesthetes, and at once we came across the name of Carol Steen, a painter. We saw some beautiful coloured paintings she had made, very alive, very inspiring. We sent her an email, the reply was instantaneous. Yes-we could call a number, and we did so. A gentle voice answered and we explained we were exploring synesthesia for our new play.

A relationship started by email and one day in January 2014 in New York City, we met Carol. She brought two envelopes in which were two luminous, vibrant, circles dedicated to each of us-They were radiant and we instantly named them Mandalas.

More and more astonishingly beautiful mandalas followed.

We are now very happy to be able to share them with the people who will come to the Polonsky Shakespeare Theatre and enter our Valley.

\section{CAROL STEEN AND HER PROCESS}

In 2009, Ethan Swan, a former curator at the New Museum wrote, "Carol Steen is a painter and sculptor of vigorously expressive, abstract work. She draws inspiration from her experiences with synesthesia." Steen says that when hearing sounds, or experiencing the touch of acupuncture needles, she sees vivid, brilliantly colored, moving shapes and always has. They appear instantly to her on a black background that is as dark and rich as silk velvet. She paints and sculpts what she sees from the synesthetic triggers she knows.

Last November, after becoming familiar with Peter Brook and Marie Helene Estienne's new play, the Valley of Astonishment, Steen suddenly began to see beautiful new synesthetic visions from an unknown stimulus. "I could see them only when I shut my eyes. I'd watch them appear immediately, their colors are brilliant and gemlike-emerald greens, sapphire blues, golden yellows. All the colors. The colors of light. They appear in quick moving pulses, changing constantly. Sometimes I would need to open my eyes to stop seeing them."

"In my life I have seen many synesthetic visions, but I have never seen so many beautiful, fully formed visions as these. Not knowing what triggered them I started to try to capture the essence of what I could see when I closed my eyes. Initially, I did not consider showing these works to anyone. But they kept coming and my need to tell someone grew. I told Marie-Hélène."

Steen says it has always been difficult for her to tell people that what she can see is real, that being able to see these things is a gift. She already knew that attempt- 


\section{MANDALAS: AN INSTALLATION INSPIRED BY THE VALLEY OF ASTONISHMENT}

ing to share these visions could, as it had many times before in her life, bring her either the heavy, lingering, sympathetic hand on her shoulder or the isolating pain of disbelief. Still, she says, she took a chance and told Marie-Hélène about them, then showed her one. Then more. Marie-Hélène named them: Mandalas.

In the tradition of creating Indian rangolis, Steen creates them on her computer and works only at night. She waits to begin only after three stars appear in the dark sky. She stops work before the singing of the birds announces the dawn.

"While I had created these to share only with Marie-Hélène and Peter Brook and the family of actors, musicians, and lighting director who are the Valley of Astonishment, thanks to the encouragement of Marie-Hélène I am happy to be able to show them for the first time publicly, here at the Theatre for a New Audience.

Even today, when I shut my eyes I continue to see them. And most every night I sit down to try to capture what I've seen."

CAROL STEEN is an artist, writer, curator and synesthete. She received her MFA from Cranbrook Academy of Art. Her work can be found in many public collections including The Library of Congress, the Detroit Institute of Arts, and the McLaughlin Gallery in Canada. She has had over 20 solo exhibitions and been in over 70 museum and gallery group shows. Steen has received fellowships from the MacDowell Colony, and the prestigious New York Foundation for the Arts, among others. She has participated in numerous television and radio documentaries worldwide, including "60 Minutes," BBC, and NPR, and her work is included in over 40 books and articles including the Wall Street Journal, Newsweek, and the New York Times. She is frequently invited to speak about her work at universities and museums around the world and has presented at the University of Cambridge, UK, Centro Nacional de las Artes in Mexico City, the Burchfield Penney Art Center in Buffalo, NY, and at the Royal Institution in London for the University of Sussex, April 2012. She is the Co-Founder of the American Synesthesia Association, Inc., a 501(c) (3). Her chapter on "Synesthesia and the Artistic Process," about how artists with synesthesia create, was published in the Oxford Handbook of Synesthesia, Oxford University Press, UK, 2013.

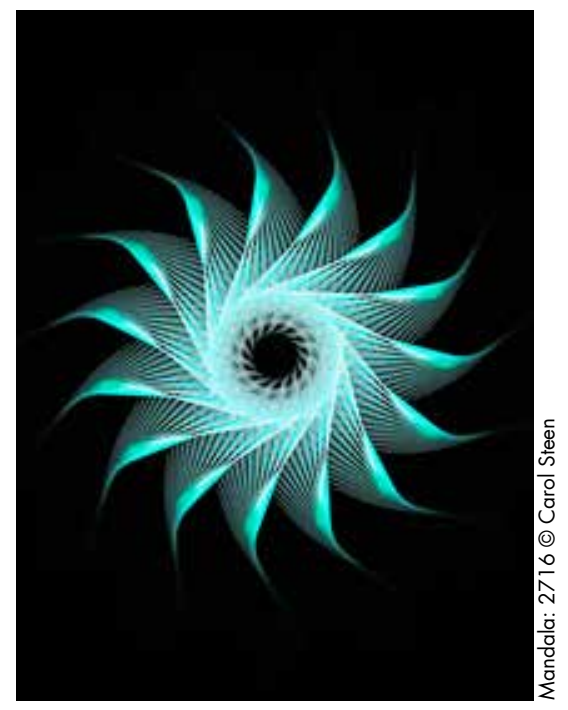




\section{DIALOGUES ON THE MAKING OF THE VALLEY OF ASTONISHMENT}

\section{AN INTERVIEW WITH PETER BROOK by JAMES WOODALL}

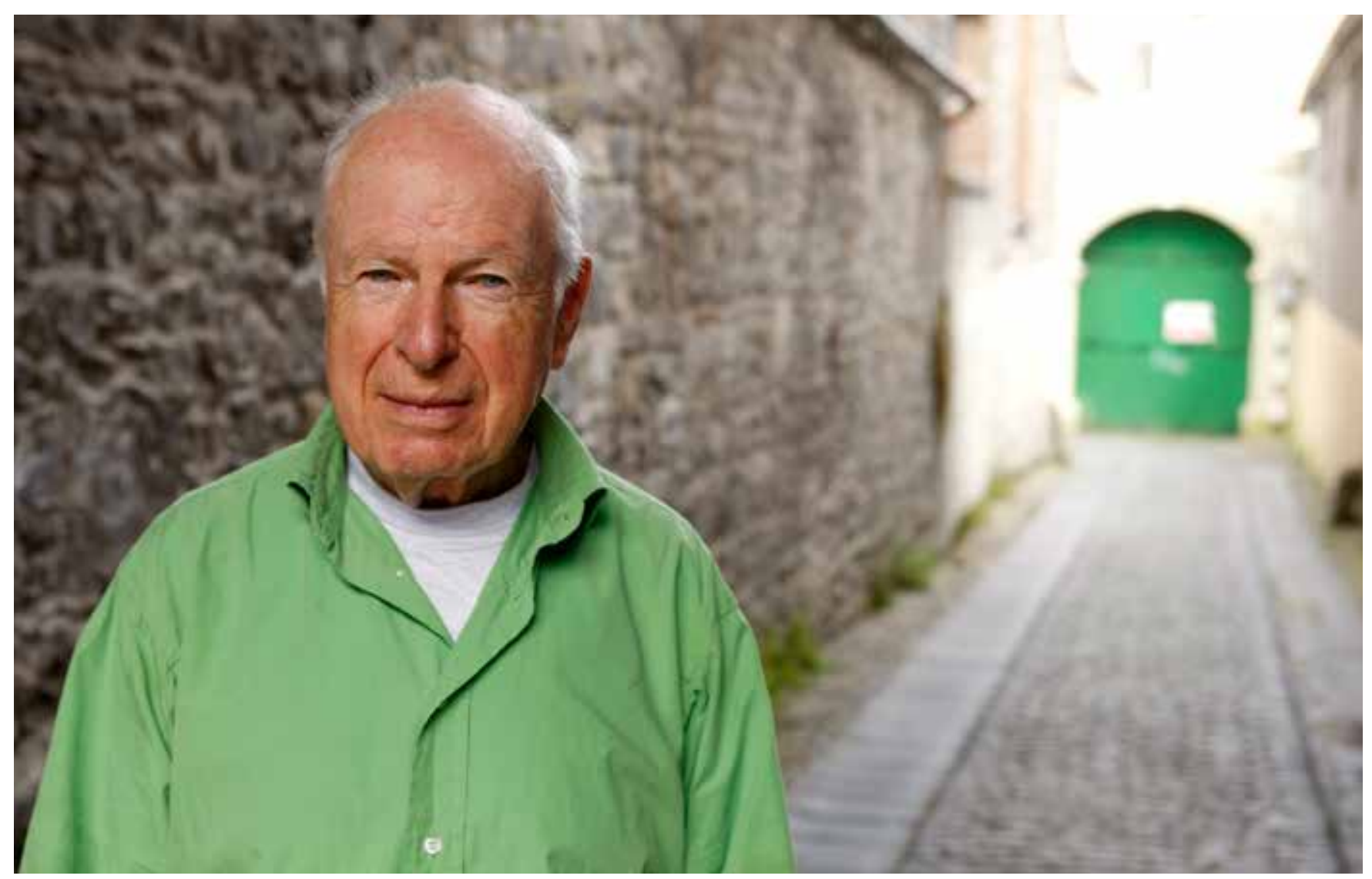

This interview with Peter Brook was conducted by James Woodall in Paris on 30 April 2014

WOODALL: Where has The Valley of Astonishment come from?

BROOK: As with everything we do, it's come from the endless give-and-take of the rehearsal process. This new play really began with research we started years ago, with a certain wish to open up certain areas, in this case how the human brain functions. Early work from this research resulted in The Man Who which we first staged at the Bouffes du Nord in 1992. I had been very inspired by Oliver Sacks and his book The Man Who Mistook His Wife for a Hat about individuals with strange conditions of the brain; people who are not mad, just physically quite ill. Oliver Sacks worked with us, and we also talked a lot to doctors and patients.
Peter Brook, photo by Colm Hogan

Six years later, this led to a study of human memory, called Je suis un phénomène ["I am a phenomenon"]. It was only ever in French. That play was itself based on a book by Oliver Sacks's model Alexander Luria, a Russian neuropsychologist. Luria's book The Mind of a Mnemonist was about Solomon Shereshevsky, a man with an extraordinary memory.

At first, Je suis un phénomène was going to be a film-and in English! Marie-Hélène Estienne and I started to build a film script. It had lots of special effects, with filming of the brain and so on, but in the end we couldn't get the money together. We'd done a huge amount of work on it, so instead turned it into a French theatre version. Shereshevsky was played by Maurice Bénichou. Yet still we felt something was 


\section{AN INTERVIEW WITH PETER BROOK by JAMES WOODALL}

incomplete. The Man Who had toured everywhere in both French and English. When the time was right, we thought, we must pick Je suis un phénomène up again.

WOODALL: How much of it has been incorporated into the new work?

BROOK: None of it is taken directly from Luria's book or from our old film script. What we have gleaned from them has been re-transformed by Marie-Hélène, not least of all in the protagonist changing from a man to a woman. I thought the ideal person for this was Kathryn Hunter. She makes a very different figure from Bénichou’s Shereshevsky. In Je suis un phénomène we turned the Bouffes into a sort of circus, which was really what Shereshevsky ended up in. He became a very unhappy man because he got caught up in the performing, and developed a greater and greater terror of each performance not being up to standard. Like an old actor, he felt such suffering if it wasn't a good performance and such relief if it was. In our new story we've found a way for Sammy, the journalist—Kathryn — to reach a point where she is liberated.

WOODALL: Did you research with patients and medics, as you did before?

BROOK: We met a marvellous neurologist, Simon Baron-Cohen, who introduced us to various people whom we don't talk about as being "treated." None of them wants to be seen, rightly, as patients, as people with a handicap. From a case in America have come the words in our play, "I know you won't take away this rich world I live in." All the people we know in London, New York and Paris have found ways of opening themselves up to us. One has become a fine writer. Another lectures and talks in universities and has students, and continues to have a special memory and relationship with colours and forms. There are endless equations in this condition known as synaesthesia. So, of course, we had to meet and listen.

WOODALL: Did you imagine, when you started with Oliver Sacks, that the topic would have such a long theatrical life, from the early 1990 s to now?

BROOK: Well, it was actually Harold Pinter who first gave me a Sacks book: Awakenings [1973]. "This is remarkable, you must read it," he said. And here was indeed something rare: a man with a gift for storytelling - the total, compassionate listening of the neurologist. But it was only a year ago we made the decision to do this play. That, for me, is the whole mystery that I cannot explain. Everything for me comes from this intuition: that the subject is just somewhere, lying waiting.

Throughout my life, when I've done a play, wellmeaning people come up to me...After The Mahabharata, it might be, "In Iceland, you know, we have a legend," or "In Sicily, there's a little-known story." Someone else might ask, "What about the Bible?" "What about the New Testament?" "Ah, but which Gospel?" The Mahabharata came from an incredibly long intuitive process. If you're more in the hands of the process than the other way round, then something will rise to the surface and say, "This is the moment." If that intuition is right, then it doesn't matter what valleys you have to go through. The intuition will find its way. That's why we're doing this now.

JAMES WOODALL is a writer, journalist and editor. His books include In Search of the Firedance, on flamenco (1992), a biography of Jorge Luis Borges (1996) and an account of musical travels in Brazil, A Simple Brazilian Song (1997). After many years in Berlin, where he wrote for the Financial Times and The Economist, James is now based in Cambridge. 


\section{THE PRODUCTION CAST AND CREATIVE TEAM}

\section{PETER BROOK (Director)}

Peter Brook was born in London in 1925. Throughout his career, he distinguished himself in various genres: theater, opera, cinema and writing.

He directed his first play there in 1943 . He then went on to direct over 70 productions in London, Paris and New York. His work with the Royal Shakespeare Company includes Love's Labour's Lost (1946), Measure for Measure (1950), Titus Andronicus (1955), King Lear (1962), Marat/Sade (1964), US (1966), A Midsummer Night's Dream (1970) and Antony and Cleopatra (1978).

In 1971, he founded with Micheline Rozan the International Centre for Theatre Research in Paris and in 1974, opened its permanent base in the Bouffes $\mathrm{du}$ Nord Theatre. There, he directed Timon of Athens, The Iks, Ubu aux Bouffes, Conference of the Birds, L'Os, The Cherry Orchard, The Mahabharata, Woza Albert!, The Tempest, The Man Who, Qui est là, Happy Days, Je suis un Phénomène, Le Costume, The Tragedy of Hamlet, Far Away, La Mort de Krishna, Ta Main dans la Mienne, The Grand Inquisitor, Tierno Bokar, Sizwe Banzi, Fragments, Warum Warum, Love is my Sin, 11 and 12, Une Flûte Enchantée (opera) and lately The Suit (2012) - many of these performing both in French and English.

In opera, he directed La Bohème, Boris Godounov, The Olympians, Salomé and Le Nozze de Figaro at Covent Garden; Faust and Eugene Onegin at the Metropolitan Opera House, New York, La Tragédie de Carmen and Impressions of Pelleas, at the Bouffes du Nord, Paris and Don Giovanni for the Aix en Provence Festival.

Peter Brook's autobiography, Threads of Time, was published in 1998 and joins other titles including The Empty Space (1968) - translated into over 15 languages, The Shifting Point (1987), There are no Secrets (1993), Evoking (and Forgetting) Shakespeare (1999) and With Grotowski (2009).

His films include Moderato Cantabile (1959), Lord of the Flies (1963), Maratl Sade (1967), King Lear (1969), Meetings with Remarkable Men (1976), The Mahabharata (1989) and The Tragedy Of Hamlet (2002, TV).

\section{MARIE-HÉLÈNE ESTIENNE (Director)}

In 1974, she worked with Peter Brook on the casting for Timon of Athens, and consequently joined the Centre International de Créations Théâtrales (CICT) for the creation of Ubu aux Bouffes in 1977.

She was Peter Brook's assistant on La tragédie de Carmen, Le Mahabharata, and collaborated to the staging of The Tempest, Impressions de Pelléas, Woza Albert!', La tragédie d'Hamlet (2000). She worked on the dramaturgy of Qui est là. With Peter Brook, she co-authored L'homme qui and Je suis un phénomène shown at the Théâtre des Bouffes du Nord. She wrote the French adaptation of the Can Themba's play Le costume and Sizwe Bansi est mort by authors Athol Fugard, John Kani, and Winston Ntshona.

In 2003, she wrote the French and English adaptations of Le Grand inquisiteur, based on Dostoievsky's Brothers Karamazov. She was the author of Tierno Bokar in 2005, and of the English adaptation of Eleven and Twelve by Amadou Hampaté Ba in 2009. With Peter Brook, she co-directed Fragments, five short pieces by Beckett, and again with Peter Brook and composer Franck Krawczyk, she freely adapted Mozart and Schikaneder's Die Zauberflöte into Une Flûte enchantée as well as recently The Suit.

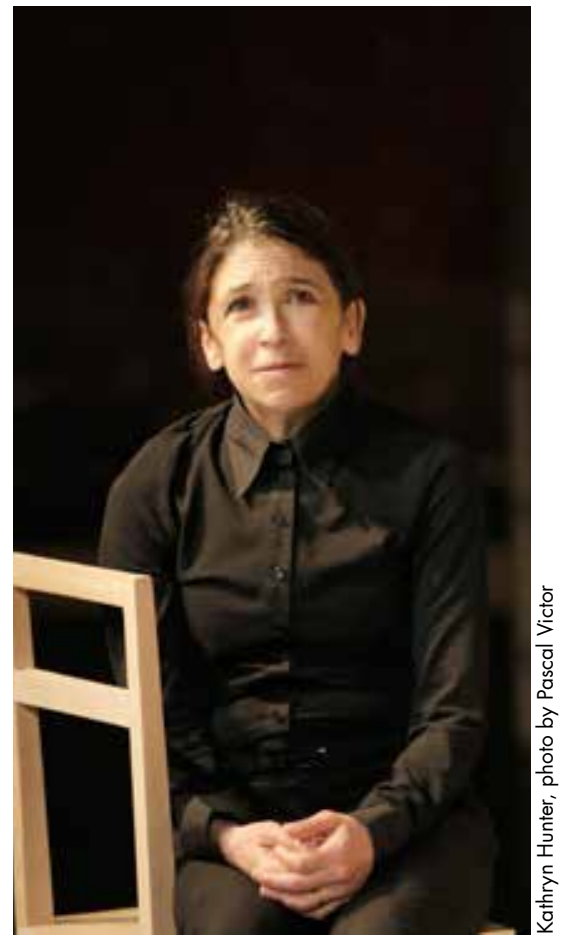




\section{KATHRYN HUNTER (Actress)}

Before The Valley of Astonishment by Peter Brook (Paris); Kathryn Hunter was part of Cards 2 (directed by Robert Lepage, Montreal); A Midsummer Night's Dream (directed by Julie Taymor, Theatre for a New Audience); The Bee (directed by Hideki Noda, London, New York and Tokyo); Fragments (directed by Peter Brook, Bouffes du Nord, Young Vic, New York and world tour); A Tender Thing (RSC Stratford); Kafka's Monkey (Young Vic, Theatre for a New Audience, UK Tour, Tokyo, Taipei, Istanbul and France); Tell Them I am Young and Beautiful (Arcola Theatre); King Lear (RSC); Antony \& Cleopatra (RSC); Celestina (Birmingham, Edinburgh Festival); Whistling Psyche (Almeida Theatre); Richard III (Shakespeare's Globe); Dona Rosita (Almeida); King Lear (directed by Helena Kaut-Howson, Young Vic); Far Away (directed by Peter Brook, Bouffes du Nord, Paris); The Rose Tattoo and The Devils (Theatr Clywd); Live Like Pigs, The Recruiting Officer, Our Country's Good (Royal Court); The Hypochondriac (Leicester Haymarket, Lyric Hammersmith); Women of Troy (Gate); Romeo and Juliet (Watermill); Spoonface Steinberg (Ambassadors, Washington); Mother Courage (Shared Experience, Ambassadors); Pericles and The Visit (National Theatre, Olivier Award for Best Actress 1990).

As member of Theatre de Complicité, Kathryn has performed in such productions as Foe, Out of the House Walked A Man, Anything for a Quiet Life, Help! I am Alive, and The Winter's Tale.

On Cinema and television, Kathryn Hunter was seen in Harry Potter \& The Order of the Phoenix, All or Nothing, Wet and Dry, Orlando, Baby of Macon, Rome, Silent Witness, NCS:Manhunt, Grushko and Maria's Child.

As Stage director, Kathryn's work includes Othello (RSC); 4.48 Psychosis (LAMDA); The Birds (National Theatre); Destination (Volcano Theatre Company); Wiseguy Scapino (Theatre Clwyd); Mr Puntila and his man Matti (Almeida, Albery and Traverse); The Glory of Living (Royal Court), Comedy of Errors and Pericles (Shakespeare's Globe). Kathryn Hunter also directed My Perfect Mind, which will return to the Young Vic this September following a sold out run in 2013.

\section{MARCELLO MAGNI (Actor)}

Marcello is a Co-Founding Member of Theatre de Complicité where he has performed and devised in 15 shows.

He studied in Paris at the Jacques Lecoq School in 1980 before moving to London. He has appeared at The Globe in The Comedy of Errors, performing the two Dromios, and Pericles. He appeared in The Birds directed by Kathryn Hunter (National Theatre), The Game of Love and Chance, Scapino and The Rose Tattoo (Theatre Clwyd), King Lear directed by Helena Kaut Housen (Young Vic), and Mother Courage (Shared Experience).

In 2003 Marcello produced and performed in Arlecchino a solo show with Commedia dell'Arte masks. Very recently Marcello has produced performed and directed Tell them that I am young and beautiful written in collaboration with Gilles Aufray at the Arcola Theatre, featuring Kathryn Hunter and Patrice Niambana.

In 2013 he taught in Poland, Canada, Italy and the UK and performed in The Bee directed By Hideki Noda (Israel, Seoul and Sibiu in Romania).

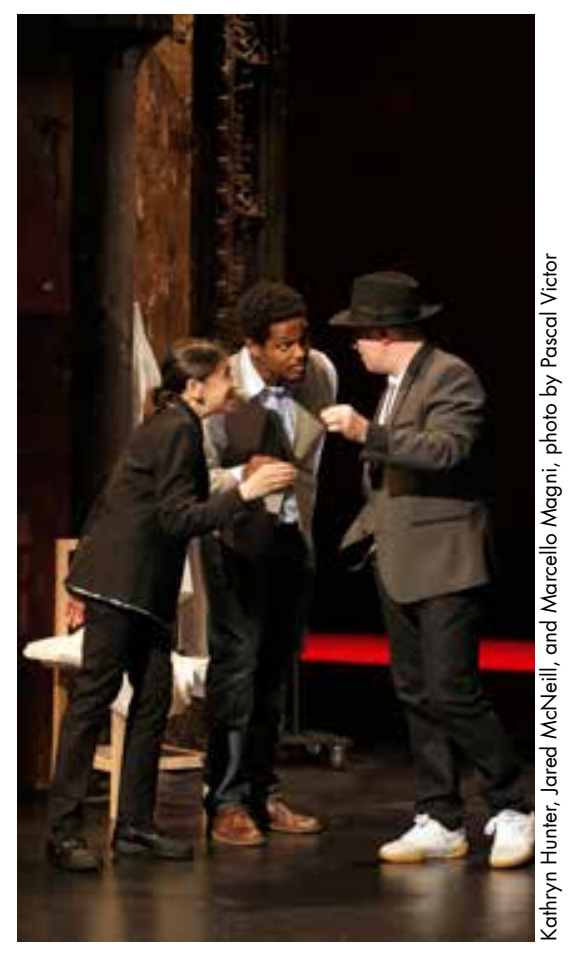

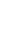




\section{THE PRODUCTION CAST AND CREATIVE TEAM}

In the summer of 2013 he rehearsed in Canada and performed in Germany the last show of Robert Lepage, Cards 2 - Hearts. He also worked with a group of young performers at the Polaresco Centre in Bergamo (Italy) by putting on stage a Japanese story The Sumo Wrestler by Yasutaka Tsutsui. He also filmed with Mike Leigh on Mr Turner.

Earlier this year, Marcello directed Tinkerbell in ShojiLland, a show written by Hideki Noda at the Tokyo Metropolitan Theatre. With Peter Brook and Marie Helene he collaborated in Fragments and A Magic Flute and in the documentary film by Simon Brook, The Tightrope. In 2015 he will perform again at the Bouffes du Nord in Fragments and in Marcel, a new show created and performed in collaboration with Jos Houben.

JARAD McNEILL (Actor)

Jared McNeill trained at Fordham University at Lincoln Center in New York City where, in 2008, he graduated with a degree in Theater and Visual Arts. His first professional role taken that same year, in Chisa Hutchinson's She Like Girls at the Lark Theatre. Jared McNeill played various roles in Peter Brook's 11 and 12 and had recently the role of Maphikela in The Suit.

Since then, he has performed in August Wilson's Fences at the Geva Theater Center, and in various chapters of Tarell Mccraney's Brothers/Sisters Trilogy at Pittsburgh's City Theater, as well as San Francisco's Marin Theater Company and American Conservatory Theater.

Most recently, Jared completed work as an understudy in The Roundabout Theater Company's production of Stephen Karam's Sons of the Prophet, as well as adopting the role of Desmond in Young Jean Lee's The Shipment, and playing in a recent New York production of Bertolt Brecht's Life of Galileo, during which he performed musical numbers on the trombone and harpsichord. Lately he went on tour with The Suit (2012) directed by Peter Brook.

\section{RAPHAËL CHAMBOUVET (Musician)}

Composer and pianist Raphael Chambouvet last worked with Peter Brook and Marie-Hélène Estienne on the UK and US premiere of The Suit at the Young Vic and BAM, prior to its international tour.

For director Emmanuel Meirieu, he composed the music for Mon Traitre, a play about the unlikely friendship between a former IRA member and a French journalist, inspired by the writings of Sorj Chalandon. It opened at Vidy Lausanne in Switzerland in April 2013, and began a European tour at Les Bouffes $\mathrm{du}$ Nord in Paris the following December. It received rave reviews and Les Echos praised its "spectacular soundscape." Prior to this he composed the music for Les Beaux Lendemains, the stage adaptation of Russell Banks' international bestseller, The Sweet Hereafter. Described by Le Monde as a "masterpiece," Chambouvet's music was compared to the great Ennio Morricone. The production opened in 2011 at Les Bouffes du Nord, then played Vidy Lausanne, and continues its European tour in 2014 to popular and critical acclaim. As a composer for theatre, his credits also include Emmanuel Meirieu's American Buffalo and Rikki Henry's Venus/Mars.

Chambouvet won the 2008 National Jazz Competition of La Defense, one of the most distinguished prizes in the jazz world, with his trio CHK. Their debut album, Slow Motion, was released the following year and was described by critic

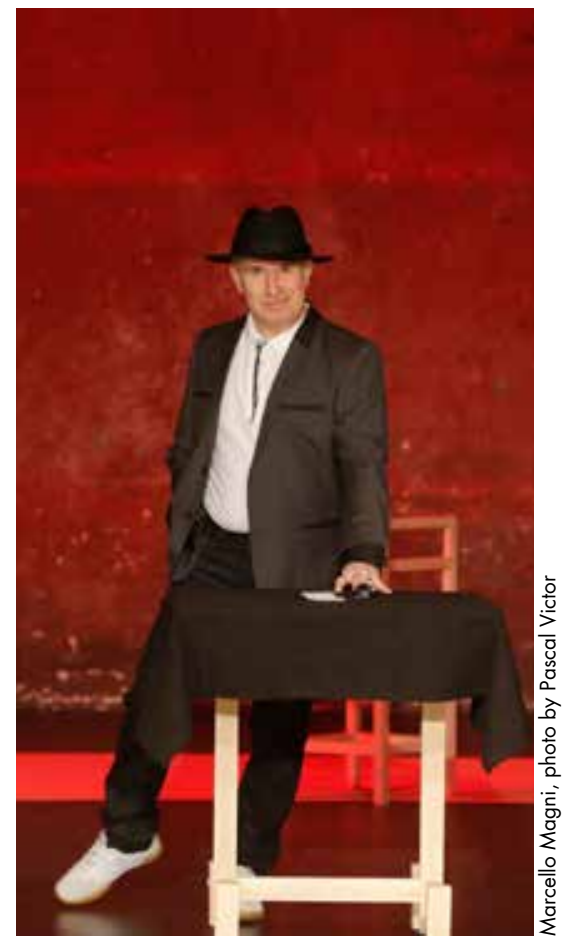

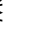


Pascal Anquetil as having: "seriously haunting grooves, heady themes, infectious melodies that capsize the soul with their poignant simplicity." Over the past decade Chambouvet has performed extensively across Europe with other jazz, soul and pop artists. His soul band Mr Day released two albums Small Fry and Dry Up in the Sun with Favourite Records, and received airplay on the BBC with notable praise from DJ Gilles Peterson. Their song "Party Party" was recently featured in the hit ABC series "Mr Sunshine" starring Matthew Perry.

Screen credits include a number of independent shorts, including the animated film Omertà which won a Best Original Music prize at Aniwow! Beijing International Animation Film Festival. The animation was screened at Futuroscope Poitiers and broadcast on Canal+ in 2012. He also composed original music for silent films including Frank Capra's The Matinee Idol for the Lumiere Festival in Lyon in 2011 and 2012.

Chambouvet graduated from the National Music Academy of Lyon in 2000 with a first prize in piano jazz, and is the recipient of a Masters degree in Music Applied To the Visual Arts from the University of Lyon.

\section{TOSHI TSUCHITORI (Musician)}

Toshi Tsuchitori was born in Kagawa prefecture of Japan in 1950 and began performing on Japanese traditional drums at an early age. Since the 1970s he has performed internationally with specialists in free improvisation such as Milford Graves, Steve Lacy, Derek Baily and others.

He began working with Peter Brook's theatre group in 1976, and has since created the music for productions including Ubu, The Conference of the Birds, L'Os, The Mahabharata, The Tempest, The Tragedy of Hamlet, Eleven and Twelve and Tierno Bokar.

He has studied traditional music from all over the world and for over a decade has been researching the earliest strata of Japanese music and presenting the results as musical performances. He has released a series of three recordings of prehistoric Japanese sounds entitled "Dotaku," "Sanukaito" and "Jomonko."

Recently he researched and played ancient music in the prehistoric painted cave of France.

Tsuchitori has also been collaborating with traditional master musician Harue Momoyama since bulding a studio together in 1988, working both local villagers and international artists.

Toshi has many CD recording and has written three books: an autobiography, called Spiral Arms, a study of the music of prehistoric Japan, The Sounds of Jomon, and The Sound of Painted Cave, about origin of music.

PHILIPPE VIALATTE (Lighting Designer)

Philippe Vialatte started up at the Théâtre des Bouffes du Nord in 1985 as a light operator on Le Mahabharata, directed by Peter Brook. He assisted Jean Kalman for the light design of Woza Albert! and La Tempête, directed by Peter Brook.

Since the creation of The Man Who in Paris in 1993, he has designed the lights for all the plays directed by Peter Brook in the Theatre des Bouffes du Nord: Qui est là, Je suis un phénomène, Le Costume, The Tragedy of Hamlet, Far Away, La mort de Krishna, La Tragédie d'Hamlet, Ta main dans la mienne, Tierno 


\section{THE PRODUCTION CAST AND CREATIVE TEAM}

Bokar, Le Grand Inquisiteur, Sizwe Banzi est mort, Fragments, 11 and 12, and recently A Magic Flute.

He follows all these plays on tour and in each space redesigns and adapts the light of each show.

RICHARD A. HODGE (Stage Manager)

Off-Broadway: TRIBES, Our Town, Adding Machine: A Musical, BUG, Mistakes Were Made, Orson's Shadow, Red Light Winter (Barrow Street Theatre). Nikolia and the Others, When The Rain Stops Falling (Lincoln Center Mitzi Newhouse). The Heir Apparent (Classic Stage Company) Women or Nothing (The Atlantic Theater Co.) Killer Joe, Underneath The Lintel (Soho Playhouse). Kindness (Playwrights Horizons). Other New York: Stop The Virgens (St. Ann's Warehouse) Los Angeles: TRIBES (Mark Taper), Our Town (The Broad). International: Stop The Virgens (Sydney Opera House). Girl Blog From Iraq: Baghdad Burning (Pleasance Courtyard: Edinburgh)

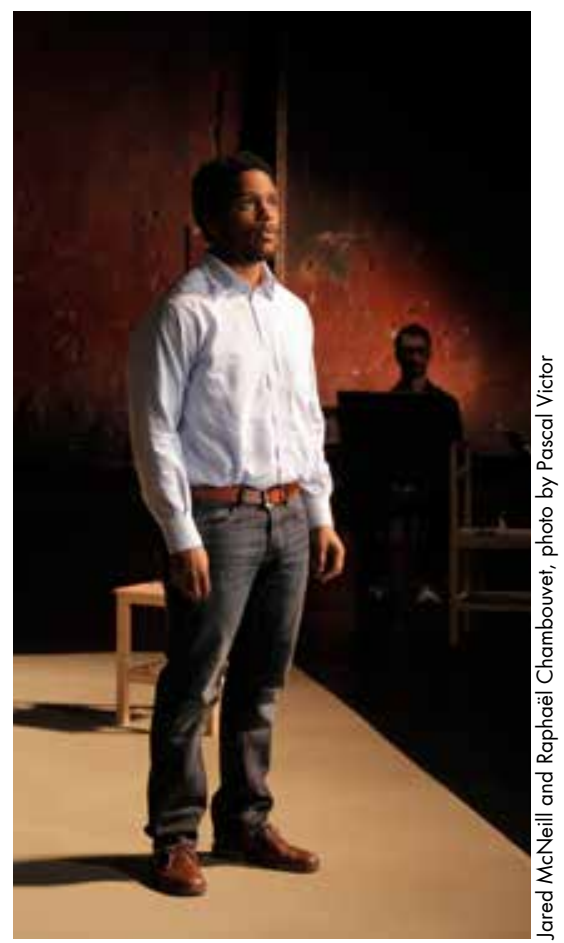




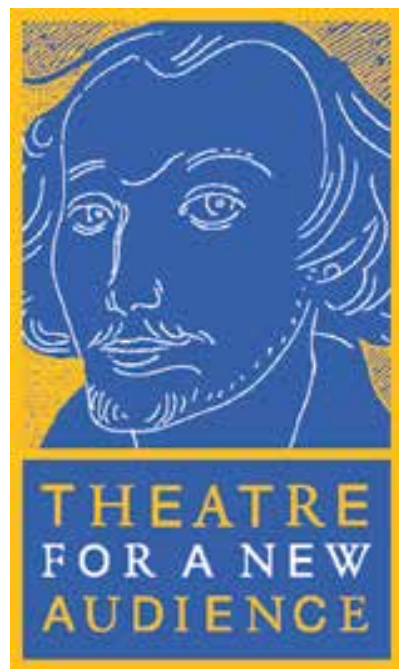

\section{STAFF}

Founding Artistic Director Jeffrey Horowitz Managing Director Dorothy Ryan General Manager Michael Page Director of Institutional Advancement James J. Lynes

Development Director Whitney Estrin Finance Director Mary Sormeley Education Director Katie Miller Director of Marketing \& Communications Nella Vera

Manager of Humanities Programs Carie Donnelson

Institutional Giving Manager Heather Violanti

Production Manager Kat Tharp Facilities Manager Joshua Newman Theatre Manager Courtney F. Caldwell Technical Supervisor Dave Nelson Associate Artistic Director Arin Arbus Associate Producer Susanna Gellert Assistant General Manager Rose Bochner Associate Finance Director Michelle Gilligan

Education Associate Rachel Friedman Development Associate Jessica Angima Marketing Manager Yelena Sayko Audience Engagement Manager \& Press Assistant Alix Milne Associate to the Managing Director Erin Frisbie

Facilities Associate Rashawn Caldwell Humanities Intern Kelsey Shapira

\section{About Theatre for a New Audience}

Founded in 1979 by Jeffrey Horowitz, the mission of Theatre for a New Audience is to develop and vitalize the performance and study of Shakespeare and classic drama. Theatre for a New Audience produces for audiences Off-Broadway and has also toured nationally, internationally and to Broadway. We are guided in our work by five core values: a reverence for language, a spirit of adventure, a commitment to diversity, a dedication to learning, and a spirit of service. These values inform what we do with artists, how we interact with audiences, and how we manage our organization.

\section{Theatre for a New Audience Education Programs}

Theatre for a New Audience is an award-winning company recognized for artistic excellence. Our education programs introduce students to Shakespeare and other classics with the same artistic integrity that we apply to our productions. Through our unique and exciting methodology, students engage in hands-on learning that involves all aspects of literacy set in the context of theatre education. Our residencies are structured to address City and State Learning Standards both in English Language Arts and the Arts, the New York City DOE's Curriculum Blueprint for Teaching and Learning in Theater, and the Common Core Learning Standards for English Language Arts. Begun in 1984, our programs have served more than 126,000 students, ages 9 through 18, in New York City Public Schools city-wide.

\section{A New Home in Brooklyn: Theatre for a New Audience's Polonsky Shakespeare Center}

After 33 seasons of award-winning and internationally-acclaimed productions, Theatre for a New Audience's Polonsky Shakespeare Center is a centerpiece of the Brooklyn Cultural District.

Designed by celebrated architect Hugh Hardy, the Theatre's Polonsky Shakespeare Center is the first theatre in New York designed and built expressly for classic drama since Lincoln Center's Vivian Beaumont in the 1960s. The 27,500 square-foot facility is a unique performance space in New York. The 299-seat Samuel H. Scripps Mainstage, inspired by the Cottesloe at London's National Theatre, combines an Elizabethan courtyard theatre with modern theatre technology that allows the stage and seating to be arranged in seven configurations. The new facility also includes the Theodore C. Rogers Studio (a 50-seat rehearsal/performance studio), and theatrical support spaces. The City of New York-developed Arts Plaza, designed by landscape architect Ken Smith, creates a natural gathering place around the building. In addition, Polonsky Shakespeare Center is also one of the few sustainable (green) theatres in the country, with an anticipated LEEDNC Silver rating from the United States Green Building Council.

Now with a home of its own, Theatre for a New Audience is contributing to the continued renaissance of Downtown Brooklyn. In addition to its season of plays, the Theatre is expanding its education and humanities offerings to include lectures and activities for families, as well as seminars, workshops, and other activities for artists, scholars, and families. When not in use by the Theatre, its new facility is available for rental, bringing much needed affordable performing and rehearsal space to the community.
BOARD OF DIRECTORS

Chairman:

President:

Henry Christensen III

Jeffrey Horowitz

Vice President and Secretary Dorothy Ryan

Members

Robert Arnow

John Berendt*

Cicely Berry, CBE, Hon. D.Lit ${ }^{\star}$

Katherine Borowitz

Marlène Brody

Sally Brody

Robert Buckholz

Zoë Caldwell*

Robert A. Caro*

Merle Debuskey*

Dr. Sharon Dunn*

Dr. Charlotte K. Frank

Sir Peter Hall*

Dana Ivey *

John J. Kerr, Jr.

Seymour H. Lesser

William F. Lloyd

Larry M. Loeb

Catherine Maciariello*

Audrey Heffernan Meyer

Caroline Niemczyk

Janet C. Olshansky

Rachel Polonsky

Theodore C. Rogers

Philip R. Rotner

Mark Rylance*

Robert T. Schaffner

Daryl D. Smith

Susan Stockel

Michael Stranahan

Julie Taymor*

John Turturro*

Monica G-S. Wambold

Jane Wells

Frederick Wiseman *

Emeritus

Francine Ballan

${ }^{\star}$ Artistic Council 


\section{THEATRE FOR A NEW AUDIENCE MAJOR SUPPORTERS}

Even with capacity audiences, ticket sales account for a small portion of our operating costs. The Theatre expresses its deepest thanks to the following Foundations, Corporations Government Agencies and Individuals for their generous support of the Theatre's Humanities, Education, and Outreach programs.

The $360^{\circ}$ Series: Viewfinders has been made possible in part by a major grant from the National Endowment for the Humanities: Celebrating 50 Years of Excellence. Any views, findings, conclusions, or recommendations expressed in this Viewfinder, do not necessarily represent those of the National Endowment for the Humanities.

A Challenge Grant from the NEH is being matched 3:1 to create a \$1.7 million Humanities endowment fund to support these programs in perpetuity. Leading matching gifts to the NEH grant were provided by Joan and Robert Arnow, Norman and Elaine Brodsky, The Durst Organization, Perry and Marty Granoff, Stephanie and Tim Ingrassia, John J. Kerr \& Nora Wren Kerr, Litowitz Foundation, Inc., Robert and Wendy MacDonald, Sandy and Stephen Perlbinder, The Prospect Hill Foundation, Inc., and Theodore C. Rogers, and from purchasers in the Theatre's Seat for Shakespeare Campaign.

For more information on naming a seat or making a gift to the NEH match, please contact James Lynes, Director of Institutional Advancement, at 212-229-2819 x29, or by email at jlynes@tfana.org.
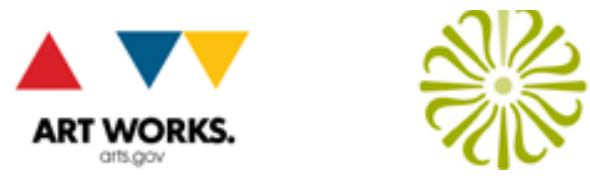

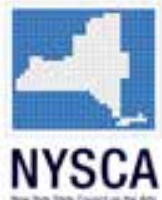

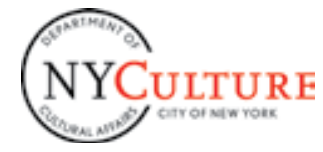

FOR THE

HUMANITIES

Theatre for a New Audience's productions and education programs receive support from the New York State Council on the Arts with the support of Governor Andrew Cuomo and the New York State Legislature; and from the New York City Department of Cultural Affairs in partnership with the City Council. The Valley of Astonishment was made possible, in part, by support from the National Endowment for the Arts

Additional support for these programs is provided by the generosity of the following Foundations and Corporations through their direct support of the Theatre's Education programs and through their general operating grants to the Theatre's Annual Fund:

\section{PRINCIPAL BENEFACTORS}

The Andrew W. Mellon Foundation

Bloomberg Philanthropies

The SHS Foundation

\section{LEADING BENEFACTORS}

\section{Deloitte LLP}

Sidney E. Frank Foundation

The Shubert Foundation, Inc.

\section{MAJOR BENEFACTORS}

The Gladys Krieble Delmas Foundation

The Gilman Foundation

The Hearst Corporation

The DuBose and Dorothy Heyward Memorial Fund

Kramer Levin Naftalis \& Frankel LLP

Latham \& Watkins LLP

The Fan Fox and Leslie R. Samuels Foundation

Sidley Austin LLP

The Harold and Mimi Steinberg Charitable Trust

\section{SUSTAINING BENEFACTORS}

The Achelis Foundation

The Howard Bayne Fund

The Geen Family Foundation

Jean and Louis Dreyfus Foundation, Inc.

The Educational Foundation of America

King \& Spalding LLP

Lambent Foundation

Litowitz Foundation, Inc.

Loeb \& Loeb LLP

The Macy's Foundation

Orrick, Herrington \& Sutcliffe LLP

Paul, Weiss, Rifkind, Wharton \& Garrison

The Rifkind Family Foundation

Rudin Family Foundation, Fiona and Eric Rudin

The Seth Sprague Educational and Charitable Foundation

Skadden, Arps, Slate, Meagher \& Flom LLP

Wiggin and Dana LLP

\section{PRODUCERS CIRCLE- \\ THE ARTISTIC DIRECTOR'S SOCIETY \\ Akin Gump Strauss Hauer \& Feld, LLP}

Axe-Houghton Foundation

Bingham McCutchen

Bulova Stetson Foundation

Consolidated Edison Company of New York, Inc.

Forest City Ratner Companies

Gibson, Dunn \& Crutcher LLP

Hughes, Hubbard \& Reed LLP

Michael Tuch Foundation, Inc.

Winston \& Strawn LLP

\section{PRODUCERS CIRCLE-EXECUTIVE}

Arnold \& Porter LLP

DeWitt Stern Group, Inc.

The Joseph \& Sally Handleman Foundation Trust A

The Irving Harris Foundation

PRODUCERS CIRCLE-ASSOCIATE

Actors' Equity Foundation, Inc.

Barbara Bell Cumming Foundation

Kinder Morgan Foundation

Lucille Lortel Foundation 
WWW.TFANA. ORG 